Research Article

\title{
Cytotoxic Phenolic Compounds from Fruit Glandular Trichomes of Macaranga tanarius
}

\author{
Thi Mai Huong Doan $\mathbb{D}^{1,2}$ Thuy Linh Nguyen, ${ }^{1}$ Thi Thanh Van Trinh, ${ }^{1}$ Van Nam Vu, ${ }^{1}$ \\ Thi Dao Phi, ${ }^{1}$ Marc Litaudon, ${ }^{3}$ Fanny Roussi, ${ }^{3}$ Van Minh Chau, ${ }^{1}$ and \\ Van Cuong Pham $\mathbb{D}^{1,2}$ \\ ${ }^{1}$ Advanced Center for Bioorganic Chemistry, Institute of Marine Biochemistry, Vietnam Academy of Science and Technology, \\ 18 Hoang Quoc Viet, Caugiay, Hanoi, Vietnam \\ ${ }^{2}$ Graduate University of Science and Technology, VAST, 18 Hoang Quoc Viet, Caugiay, Hanoi, Vietnam \\ ${ }^{3}$ Institut de Chimie des Substances Naturelles, CNRS, ICSN UPR2301, University of Paris-Saclay, 91198 Gif-sur-Yvette, France
}

Correspondence should be addressed to Thi Mai Huong Doan; huongdm@imbc.vast.vn and

Van Cuong Pham; phamvc@imbc.vast.vn

Received 4 July 2019; Revised 7 September 2019; Accepted 12 September 2019; Published 13 October 2019

Academic Editor: Serban C. Moldoveanu

Copyright (C) 2019 Thi Mai Huong Doan et al. This is an open access article distributed under the Creative Commons Attribution License, which permits unrestricted use, distribution, and reproduction in any medium, provided the original work is properly cited.

\begin{abstract}
A new flavonoid, macatanarin D (1), together with five known stilbenes (2-6), was isolated from fruit glandular trichomes of Macaranga tanarius. Their structures were elucidated on the basis of spectroscopic methods and through comparison with data reported in the literature. All isolated compounds were evaluated for their cytotoxic activities against KB and MCF-7 cell lines. Compounds 3, 4, and 5 showed the strongest activities against both cell lines with $\mathrm{IC}_{50}$ values in the range of $0.03-0.12 \mu \mathrm{M}$, and compound 2 only showed a significant cytotoxicity against $\mathrm{KB}$ cell line $\left(\mathrm{IC}_{50}=0.26 \mu \mathrm{M}\right)$ and a moderate cytotoxicity against MCF-7 $\left(\mathrm{IC}_{50}=10.4 \mu \mathrm{M}\right)$. Compounds 1 and $\mathbf{6}$ showed weak cytotoxic activities against KB cell line with $\mathrm{IC}_{50}$ values of 29.3 and $24.7 \mu \mathrm{M}$, respectively.
\end{abstract}

\section{Introduction}

Macaranga (Euphorbiaceae) is a large genus of about 300 species mainly distributed in Southern Asia, of which 13 species are native to Vietnam $[1,2]$. In Vietnam, several species of this genus known as "Ba soi" have been used in traditional medicine for the treatment of swellings, wounds, and diarrhoea $[2,3]$. Phytochemical studies of Macaranga species have led to the discovery of various compounds such as flavonoids [4-6] and stilbenes $[7,8]$, which are regarded as the main constituents [9]. They are responsible for the cytotoxic and antioxidant activities generally found in plants of this genus [9]. Macaranga tanarius is known as "Bach dan nam" in Vietnam. The dried roots are used as an emetic agent, whereas fresh leaves are used as an anti-inflammatory drug to heal wounds [10].

A previous chemical investigation of Macaranga tanarius fruits led to the isolation of seven new and six known prenylated stilbenes [11]. In another study, it was also demonstrated that vedelianin, one of the most potent $\mathrm{cy}$ totoxic metabolites of this chemical series, was located in the glandular trichomes present on the surface of fruits of this species [12]. Plant glandular trichomes are considered to be natural cell factories of high biotechnological interest [13]. This result, combined with the highly cytotoxic activity of an AcOEt extract of glandular trichomes of Macaranga tanarius fruits, led us to further investigate chemically these epidermal outgrowths. Herein, we report the isolation of five known prenylated stilbenes (2-6) and the structure elucidation of the new flavonoid macatanarin $\mathrm{D}(\mathbf{1})$ and their cytotoxic activities against KB and MCF-7 cancer cell lines.

\section{Materials and Methods}

2.1. General Experimental Procedures. Optical rotations were determined on a JASCO P-2000 polarimeter (Hachioji, 
Tokyo, Japan). High-resolution ESIMS was measured on a Varian 910 spectrometer (Varian, California, USA). IR spectra were obtained on a Bruker 23 TENSOR 37 FT-IR spectrometer (Bruker, Billerica, MA, USA). UV spectra were measured using a UV-1601 spectrometer. The ${ }^{1} \mathrm{H}$ and ${ }^{13} \mathrm{C}$, HMQC, HMBC, NOESY/ROESY, and COSY NMR spectra were recorded on a Bruker AM500 FTNMR spectrometer (Bruker, Billerica, MA, USA), and tetramethylsilane (TMS) was used as an internal standard. Column chromatography (CC) was performed using a silica gel (Kieselgel 60, 70230 mesh and 230-400 mesh, Merck, Darmstadt, Germany) or Sephadex ${ }^{\mathrm{TM}}$ LH-20 (Supelco, Bellefonte, PA, USA). Thinlayer chromatography (TLC) used precoated silica gel 60 F254 (1.05554.0001, Merck, Darmstadt, Germany), and compounds were visualized by spraying with aqueous $10 \% \mathrm{H}_{2} \mathrm{SO}_{4}$ and heating for $1.5-2 \mathrm{~min}$.

2.2. Plant Samples. The fruits of Macaranga tanarius were collected in A Luoi, Thua Thien Hue, Vietnam, in June 2017 and were identified by Dr. Nguyen The Cuong of the Vietnam National Museum of Nature, Vietnam Academy of Science and Technology (VAST). A voucher specimen (VN-2406) was deposited at the Herbarium of the Institute of Ecology and Biological Resources of the Vietnam Academy of Science and Technology (VAST), Hanoi, Vietnam. The harvested fruits were carefully dried in a confined space at $40^{\circ} \mathrm{C}$ for 48 hours. The glandular trichomes were then separated and collected for further investigations by gently hand-rubbing dried fruits on a sieve of stainless-steel mesh.

2.3. Extraction and Isolation. Dry glandular trichomes $(200 \mathrm{~g})$ were successively extracted with $\mathrm{EtOH}(5 \times 0.5 \mathrm{~L})$. The extracts were combined and concentrated under diminished pressure. The residue $(24 \mathrm{~g})$ was suspended in water $(70 \mathrm{~mL})$ and extracted successively with $n$-hexane and EtOAc. The $n$-hexane and EtOAc solutions were concentrated under reduced pressure to afford $4.9 \mathrm{~g}$ and $10.5 \mathrm{~g}$, respectively. The water solution was concentrated under vacuum to give $7.1 \mathrm{~g}$ of dry extract.

The EtOAc extract $(10.5 \mathrm{~g})$ was subjected to silica gel column chromatography (CC) eluted with a solvent gradient of $\mathrm{CH}_{2} \mathrm{Cl}_{2} / \mathrm{MeOH}$ to yield 9 fractions (F1-F9). F4 (1.5 g) was subjected to a $\mathrm{CC}$ on silica gel, eluting with $\mathrm{CH}_{2} \mathrm{Cl}_{2} / \mathrm{MeOH}$ gradient to obtain 5 subfractions (F4.1-F4.5). Subfraction F4.3 (137 mg) was purified on a Sephadex LH-20 column $(100 \% \mathrm{MeOH})$ to yield compound 4 (pale yellow solid, $10.1 \mathrm{mg}$, yield $=0.005 \%)$. Subfraction F4.4 (99.6 mg) was purified on a Sephadex LH-20 column (100\% MeOH) and then repurified by $\mathrm{CC}$ on silica gel $\left(\mathrm{CH}_{2} \mathrm{Cl}_{2} / \mathrm{MeOH}\right.$ gradient) to provide compound 3 (pale yellow solid, $17.3 \mathrm{mg}$, yield $=0.0087 \%$ ) and compound 5 (pale yellow solid, $15.5 \mathrm{mg}$, yield $=0.0078 \%)$. Fraction F6 $(2.3 \mathrm{~g})$ was subjected to a $\mathrm{CC}$ on silica gel, eluting with $\mathrm{CH}_{2} \mathrm{Cl}_{2} / \mathrm{MeOH}$ gradient to obtain 7 subfractions (F6.1-F6.7). Subfraction F6.5 (57 mg) was purified on a Sephadex LH-20 column $(100 \% \mathrm{MeOH})$ to provide compound 2 (pale yellow solid, $9.2 \mathrm{mg}$, yield $=0.0046 \%$ ) and compound 1 (yellow powder, $4.4 \mathrm{mg}$, yield $=0.0022 \%)$. Fraction F7 $(1.9 \mathrm{~g})$ was subjected to a CC on silica gel, eluting with $\mathrm{CH}_{2} \mathrm{Cl}_{2} / \mathrm{MeOH}$ gradient to obtain 6 subfractions (F7.1-F7.6). Subfraction F7.4 (97 mg) was purified on a Sephadex LH-20 column $\left(\mathrm{CH}_{2} \mathrm{Cl}_{2} / \mathrm{MeOH}\right.$ : $1.5 /$ 8.5 ) to yield compound 6 (pale yellow solid, $4.7 \mathrm{mg}$, yield $=0.0024 \%)$.

Macatanarin D (1): yellow powder; $[\alpha]^{29}{ }_{D}+33.9(c 0.05$, $\mathrm{MeOH})$; FT-IR $(\mathrm{KBr}) \nu_{\text {max }}: 3414,2928,1725,1656,1610$, $1475,13741163,1087,967,894,745,647$; UV (MeOH) $\lambda_{\max }$ $(\log \varepsilon): 210$ (2.6), 271 (1.25), 327 (1.15), $366(1.20) ;{ }^{1} \mathrm{H}$ and ${ }^{13}$ C-NMR spectral data (see Table 1); HR-ESI MS: $\mathrm{m} / \mathrm{z}$ 481.1864 $[\mathrm{M}+\mathrm{H}]^{+}$(calcd. for $\mathrm{C}_{27} \mathrm{H}_{29} \mathrm{O}_{8}, 481.1862$ ).

2.4. Cytotoxic Assay. The cytotoxicity assays were carried out in triplicate in 96-well microtiter plates against KB cell line (mouth epidermal carcinoma cells) and MCF-7 cell line (breast cancer cells). Cells were maintained in Dulbecco's DMEM medium, supplemented with $10 \%$ fetal calf serum, L-glutamine $(2 \mathrm{mM})$, penicillin $\mathrm{G}(100 \mathrm{UI} / \mathrm{mL})$, streptomycin $(100 \mu \mathrm{g} / \mathrm{mL})$, and gentamicin $(10 \mu \mathrm{g} / \mathrm{mL})$. Stock solutions of compounds were prepared in DMSO/ $\mathrm{H}_{2} \mathrm{O}(1 / 9)$, and the cytotoxicity assays were carried out in 96-well microtiter plates against cancer or normal cells $\left(3 \times 10^{3}\right.$ cells $\left./ \mathrm{mL}\right)$ using a modification of the published method [14]. After $72 \mathrm{~h}$ incubation at $37^{\circ} \mathrm{C}$ in air/ $\mathrm{CO}_{2}(95$ : $5)$ with or without test compounds, cell growth was estimated by colorimetric measurement of living cells stained by neutral red. Optical density was determined at $540 \mathrm{~nm}$ with a Titertek Multiskan photometer. The $\mathrm{IC}_{50}$ value was defined as the concentration of the sample necessary to inhibit the cell growth to $50 \%$ of the control. Ellipticine was used as a reference compound.

\section{Results and Discussion}

Compound $\mathbf{1}$ was isolated as a yellow powder, and its molecular formula of $\mathrm{C}_{27} \mathrm{H}_{28} \mathrm{O}_{8}$ was established by HRESIMS at $\mathrm{m} / \mathrm{z} 481.1864[\mathrm{M}+\mathrm{H}]^{+}$(calcd. for $\mathrm{C}_{27} \mathrm{H}_{29} \mathrm{O}_{8}$, 481.1862). The FT-IR showed absorption bands at $v_{\max } 3414$, 1657,1610 , and $1475 \mathrm{~cm}^{-1}$ indicating the presence of hydroxy, $\alpha, \beta$-unsaturated carbonyl and aromatic ring functionalities, respectively. The UV absorption maximum at 366,327 , and $271 \mathrm{~nm}$ was typical for a flavonol-type compound [15]. The presence of a substituted flavonol skeleton was suggested by the analysis of ${ }^{1} \mathrm{H}$ and ${ }^{13} \mathrm{C}-\mathrm{NMR}$ spectroscopic data (Table 1). The NMR spectroscopic data of $\mathbf{1}$ were similar to those of macakurzin B, which has been previously isolated from M. kurzii, except for the presence of a prenyl, acetyl, and $\mathrm{OH}$ groups [6]. In the ${ }^{1} \mathrm{H}-\mathrm{NMR}$ spectrum, the presence of an ABX system at $\delta_{\mathrm{H}} 6.92(\mathrm{~d}$, $J=8.5 \mathrm{~Hz}), 7.80(\mathrm{dd}, J=2.5,8.5 \mathrm{~Hz})$, and $7.83(\mathrm{~d}, J=2.5 \mathrm{~Hz})$ and a singlet proton at $\delta_{\mathrm{H}} 6.45$ was observed in the aromatic region. Additionally, the ${ }^{1} \mathrm{H}-\mathrm{NMR}$ data also exhibited an acetyl group at $\delta_{\mathrm{H}} 1.88(3 \mathrm{H}, \mathrm{s})$, and two isoprenoid units: a 3methyl-2-butenyl group $\left(\delta_{\mathrm{H}} 1.71\right.$ and 1.72 (each $\left.3 \mathrm{H}, \mathrm{s}\right), 5.31$ $(1 \mathrm{H}, \mathrm{t}, J=7.5 \mathrm{~Hz})$, and $3.28(2 \mathrm{H}, \mathrm{d}, J=7.5 \mathrm{~Hz}))$, and $\mathrm{a} 2,2-$ dimethyl-3-hydroxy-dihydropyrano ring $\left(\delta_{\mathrm{H}} 1.20\right.$ and 1.34 (each $3 \mathrm{H}, \mathrm{s}), 3.67(1 \mathrm{H}, \mathrm{dd}, J=5.5,7.5 \mathrm{~Hz}), 2.77(1 \mathrm{H}, \mathrm{dd}$, 
TABLe 1: NMR data for compounds 1 in DMSO- $\mathrm{d}_{6}$.

\begin{tabular}{|c|c|c|c|c|c|}
\hline Position & $\delta_{\mathrm{C}}^{\mathrm{a}}$ & $\begin{array}{c}\delta_{\mathrm{H}}^{\mathrm{b}} \text { mult. }(J \text { in } \\
\mathrm{Hz} \text { ) }\end{array}$ & Position & $\delta_{\mathrm{C}}{ }^{\mathrm{a}}$ & $\begin{array}{c}\delta_{\mathrm{H}}^{\mathrm{b}} \text { mult. }(J \text { in } \\
\mathrm{Hz})\end{array}$ \\
\hline 2 & 141.3 & - & $4^{\prime \prime}$ & 26.0 & $\begin{array}{c}2.40 \mathrm{dd}(7.5 \\
17.0) \\
2.77 \mathrm{dd}(5.5 \\
17.0)\end{array}$ \\
\hline 3 & 136.7 & - & $5^{\prime \prime}$ & 67.1 & $\begin{array}{c}3.67 \mathrm{dd}(5.5, \\
7.5)\end{array}$ \\
\hline 4 & 170.7 & - & $6^{\prime \prime}$ & 77.5 & - \\
\hline 5 & 153.2 & - & $7^{\prime \prime}$ & 25.5 & $1.34 \mathrm{~s}$ \\
\hline 6 & 104.4 & - & $8^{\prime \prime}$ & 20.4 & $1.20 \mathrm{~s}$ \\
\hline 7 & 161.1 & - & $1^{\prime \prime \prime}$ & 28.1 & $3.28 \mathrm{~d}(7.5)$ \\
\hline 8 & 93.5 & $6.45 \mathrm{~s}$ & $2^{\prime \prime \prime}$ & 122.6 & $5.31 \mathrm{~d}(7.5)$ \\
\hline 9 & 156.1 & - & $3^{\prime \prime \prime}$ & 131.6 & - \\
\hline 10 & 104.4 & - & $4^{\prime \prime \prime}$ & 17.7 & $1.71 \mathrm{~s}$ \\
\hline $1^{\prime}$ & 122.0 & - & $5^{\prime \prime \prime}$ & 25.5 & $1.72 \mathrm{~s}$ \\
\hline $2^{\prime}$ & 128.2 & $7.83 \mathrm{~d}(2.5)$ & $\mathrm{C}=\mathrm{O}$ & 172.0 & - \\
\hline $3^{\prime}$ & 127.5 & - & $\mathrm{COCH}_{3}$ & 21.5 & $1.88 \mathrm{~s}$ \\
\hline $4^{\prime}$ & 156.1 & - & $3-\mathrm{OH}$ & & $6.74 \mathrm{~s}$ \\
\hline $5^{\prime}$ & 114.9 & $6.92 \mathrm{~d}(8.5)$ & $4^{\prime}-\mathrm{OH}$ & & $7.29 \mathrm{~s}$ \\
\hline $6^{\prime}$ & 126.0 & $\begin{array}{c}7.80 \mathrm{dd}(2.5 \\
8.5)\end{array}$ & $5^{\prime \prime \prime}-\mathrm{OH}$ & & 3.09 br s \\
\hline
\end{tabular}

${ }^{a} 125 \mathrm{MHz} ;{ }^{b} 500 \mathrm{MHz}$. Assignments were made using the HSQC, HMBC, COSY, and NOESY spectra.

$J=5.5,17.0 \mathrm{~Hz})$, and $2.40(1 \mathrm{H}, \mathrm{dd}, J=7.5,17.0 \mathrm{~Hz}))$. The analysis of ${ }^{13} \mathrm{C}-\mathrm{NMR}$ data and 2D HSQC spectrum of $\mathbf{1}$ revealed the presence of 27 carbons, corresponding to a flavonol derivative with one acetyl group and two isoprene moieties (Table 1).

The HMBC correlations of $\mathrm{H}-1^{\prime \prime \prime}\left(\delta_{\mathrm{H}} 3.28\right)$ with C-2' $\left(\delta_{\mathrm{C}}\right.$ $128.2), \mathrm{C}-3^{\prime}\left(\delta_{\mathrm{C}} 127.5\right), \mathrm{C}-4^{\prime}\left(\delta_{\mathrm{C}} 156.1\right), \mathrm{C}-2^{\prime \prime \prime}\left(\delta_{\mathrm{C}} 122.6\right)$, $\mathrm{C}-3^{\prime \prime \prime}\left(\delta_{\mathrm{C}} 131.6\right)$ and $\mathrm{OH}\left(\delta_{\mathrm{H}} 7.29\right)$ with $\mathrm{C}-4^{\prime}\left(\delta_{\mathrm{C}} 156.1\right), \mathrm{C}-5^{\prime}$ $\left(\delta_{\mathrm{C}} 114.9\right)$, and $\mathrm{C}-3^{\prime}\left(\delta_{\mathrm{C}} 127.5\right)$ determined the linkage of the isoprenyl chain with $\mathrm{C}-3^{\prime}$ and position of $\mathrm{OH}$ group at $\mathrm{C}-4^{\prime}$ on ring $\mathrm{B}$ (Figure 1). Furthermore, the COSY correlations of $\mathrm{CH}_{2}-4^{\prime \prime} / \mathrm{H}-5^{\prime \prime}$ and the HMBC cross peaks of $\mathrm{H}-4^{\prime \prime}\left(\delta_{\mathrm{H}} 2.40\right.$ and 2.77) with $\mathrm{C}-5^{\prime \prime} / \mathrm{C}-6^{\prime \prime} / \mathrm{C}-6 / \mathrm{C}-5 / \mathrm{C}-7$ and $\mathrm{OH}\left(\delta_{\mathrm{H}} 3.09\right)$ with $\mathrm{C}-4^{\prime \prime}\left(\delta_{\mathrm{C}} 26.0\right), \mathrm{C}-5^{\prime \prime}\left(\delta_{\mathrm{C}} 67.1\right)$, and C-6" ${ }^{\prime \prime}\left(\delta_{\mathrm{C}} 77.5\right)$ were confirmed that the position of $\mathrm{OH}$ group was at $\mathrm{C}-5^{\prime \prime}$ of pyrano ring and 2,2-dimethyldihydropyranol moiety was attached to ring A. From the ${ }^{1} \mathrm{H}$-NMR spectrum, absence of resonance for a hydrogen-bonded hydroxy proton, led to the assumption that a free hydroxy group was not present at C-5. Two possible isomers could be considered at this stage. In the first one, the dihydropyranol moiety is fused to ring A via C-5 and C-6 and the $O$-acetyl group is located at C-7, while in the second possible isomer, the pyranol moiety is fused to ring A via C-6 and C-7 and the $O$-acetyl group is attached in position C-5. Since only the correlations of the methyl protons of acetyl group at $\delta_{\mathrm{H}} 1.88$ with methylene protons of $\mathrm{CH}_{2}-4^{\prime \prime}$ at $\delta_{\mathrm{H}} 2.40$ and 2.77 and no NOE interaction between the aromatic singlet $\mathrm{H}-8\left(\delta_{\mathrm{H}} 6.45\right)$ and the methyl protons of acetyl group were observed on the NOESY spectrum, the pyranol moiety is supposed to be attached at C- 6 and C-7 and the acetyl group in C-5 on ring $\mathrm{A}$. This suggestion agreed with NMR data found for structurally close prenylated flavonoids. In particular, when a pyrane moiety is fused via

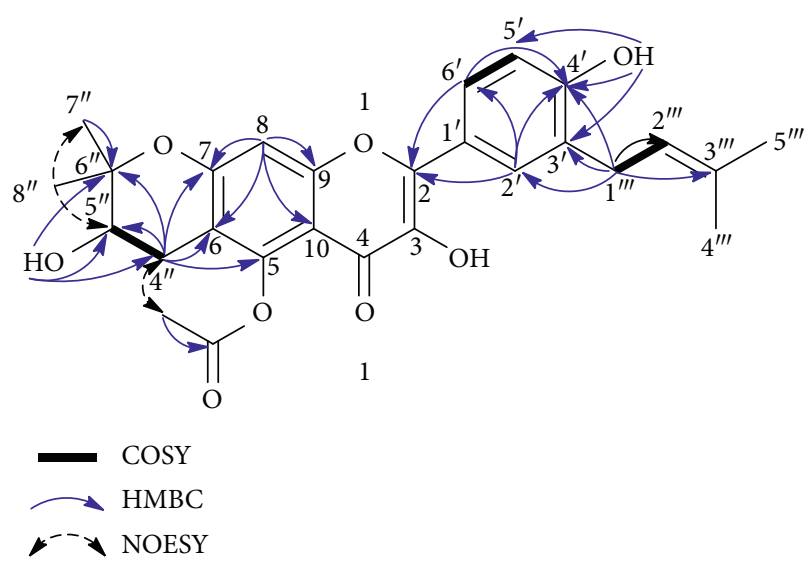

FIgUre 1: Key COSY, HMBC, and NOESY correlations for compounds 1 .

C6 and C-7 on ring A, the resonance of C-7 is around $\delta_{\mathrm{C}}$ 161.0-164.0 $\left(\delta_{\mathrm{C}} 161.2\right.$ for dinklagin $\mathrm{B}$ [16] and 163.7 for tanariflavanone B [17], $\delta_{\mathrm{C}} 161.1$ for compound 1), whereas a pyrane moiety fused via C5 and C-6 leads to a upfield-shifted carbon C-5 signal at about $155.0\left(\delta_{\mathrm{C}} 155.5\right.$ and 155.7 for vogelins I and $J$, respectively [18]).

The relative configuration of C-5" was established by proton coupling constant analysis and NOESY spectrum. The pseudoaxial orientation of $\mathrm{H}-5^{\prime \prime}$ can be deduced from its proton coupling constants with a gauche $(J=5.5 \mathrm{~Hz})$ and an anti $(7.5 \mathrm{~Hz})$. This observation was confirmed by the NOESY data analysis, which showed NOE correlations between $\mathrm{H}-5^{\prime \prime}\left(\delta_{\mathrm{H}} 3.67\right)$ and $\mathrm{CH}_{3}-7^{\prime \prime}\left(\delta_{\mathrm{H}} 1.34\right)$ and proton $\mathrm{H}_{\mathrm{b}}-4^{\prime \prime}\left(\delta_{\mathrm{H}}\right.$ $2.77)$ of the $4^{\prime \prime}-\mathrm{CH}_{2}$ group. Based on these observations, the structure of the newly isolated compound 1 was determined as 5-O-acetyl-6,7-(2,2-dimethyl-3-hydroxydihydropyrano)3 '-prenyl kaempferol (Figure 2) and named "macatanarin D."

The structures of the known stilbenes: schweinfurthin $\mathrm{H}$ (2) [19], vedelianin (3) [20], schweinfurthin F (4), schweinfurthin E (5) [19], and 4'deprenyl-mappain (6) [21] were determined by analysis of spectroscopic data and comparison with reported data. So far, about $90 \%$ of the isolated compounds come from the leaves of Macaranga genus while $10 \%$ were isolated from other plant parts such stem and root barks, fruits, seeds, and flowers. No phytochemical studies had been conducted to date on glandular trichomes of Macaranga fruits. It is important to note that collecting time clearly influences the harvesting yield of glandular trichomes. While the young fruits do not have glandular trichomes and overripe fruits contain low yield of glandular trichomes, the adult/mature fruits, with clearly visible trichome glands, give the best results. In Vietnam, it is best to harvest mature fruits in June.

Since prenylated stilbenes and flavonoids of Macaranga genus are reported to have potent cytotoxic activities [9, 22], compounds 1-6 were evaluated for their cytotoxic activity against $\mathrm{KB}$ and MCF-7 human cancer cell lines. Ellipticine was used as a reference compound. The results are shown in Table 2. Compounds $\mathbf{1}$ and $\mathbf{6}$ showed moderate cytotoxic activities against $\mathrm{KB}$ cell line with $\mathrm{IC}_{50}$ values of 29.3 and 


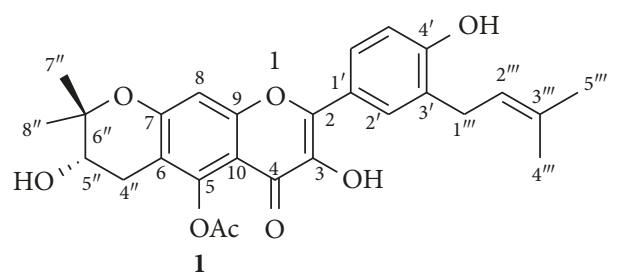<smiles>COc1cc(/C=C/c2cc(O)c3c(c2)OC(C)(C)C(O)C3)cc2c1O[C@]1(C)C[C@@H](O)[C@@H](O)C(C)(C)[C@H]1C2</smiles>

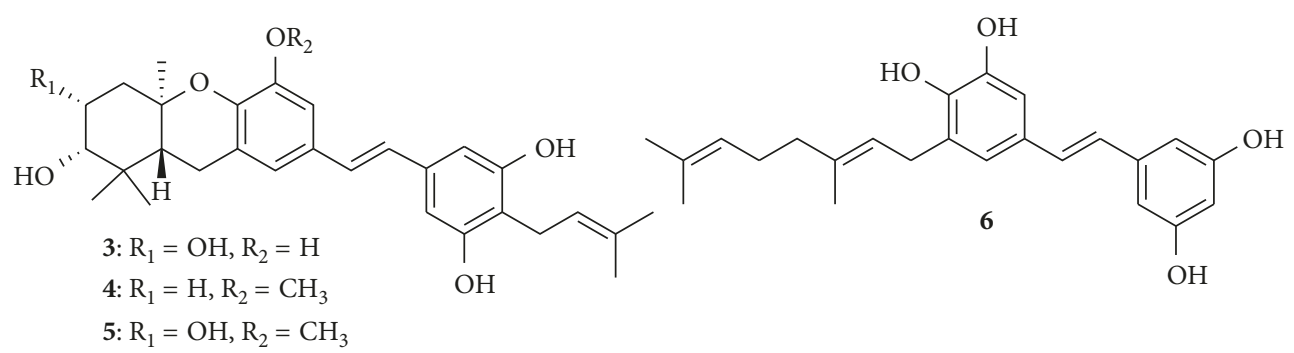

Figure 2: Structures of compounds 1-6 from fruit glandular trichomes of M. tanarius.

TABLe 2: Cytotoxic activities of compounds $\mathbf{1 - 6}$ against $\mathrm{KB}$ and MCF-7 cell lines.

\begin{tabular}{lcc}
\hline Compounds & \multicolumn{2}{c}{$\mathrm{IC}_{50}(\mu \mathrm{M})$} \\
& $\mathrm{KB}$ & MCF-7 \\
\hline $\mathbf{1}$ & $29.3 \pm 2.0$ & $81.4 \pm 3.9$ \\
$\mathbf{2}$ & $0.26 \pm 0.10$ & $10.4 \pm 1.0$ \\
$\mathbf{3}$ & $0.050 \pm 0.009$ & $0.050 \pm 0.006$ \\
$\mathbf{4}$ & $0.10 \pm 0.07$ & $0.12 \pm 0.05$ \\
$\mathbf{5}$ & $0.050 \pm 0.007$ & $0.030 \pm 0.009$ \\
$\mathbf{6}$ & $24.7 \pm 1.2$ & $82.2 \pm 3.7$ \\
Ellipticine $^{\mathrm{a}}$ & $1.3 \pm 0.2$ & $2.4 \pm 0.1$ \\
\hline
\end{tabular}

${ }^{a}$ Ellipticine was used as a positive control.

$24.7 \mu \mathrm{M}$, respectively. Compounds $3, \mathbf{4}$, and 5 showed the strongest activities against both $\mathrm{KB}$ and MCF-7 cell lines with $\mathrm{IC}_{50}$ values in the range of $0.03-0.12 \mu \mathrm{M}$, which is evenly stronger than ellipticine. It was worth noting that three aforementioned compounds possessed the same hexahydroxanthene moiety but a variable number of hydroxy groups, which may explain the difference in their cytotoxic potencies. Compound $\mathbf{2}$ also showed a significant cytotoxicity against $\mathrm{KB}$ cell line $\left(\mathrm{IC}_{50}=0.26\right)$ but compared to compounds 3,4 , and 5 , cytotoxicity appears to be much less active against the MCF-7 cell line with an $\mathrm{IC}_{50}$ value of 10.4 .

\section{Conclusion}

An undescribed flavonoid, macatanarin D (1), together with five known prenylated stilbenes (2-6) were isolated from glandular trichomes of fruits of Macaranga tanarius. Most of the compounds isolated have shown potent cytotoxic activities against the two cancer cell lines KB and MCF-7. It is postulated that these specialized metabolites are an important first line of defense against herbivorous insects and/or pathogens.

\section{Data Availability}

The data used to support the findings of this study are available from the corresponding author upon request.

\section{Conflicts of Interest}

The authors declare that there are no conflicts of interest regarding the publication of this paper.

\section{Acknowledgments}

This work was financially supported by the Vietnam Academy of Science and Technology (QTFR01.01/18-19) and the framework of International Associated Laboratory (LIA “NATPROCHEMLAB”) between the Centre National de la Recherche Scientifique (CNRS, ICSN, France) and the Vietnam Academy of Science and Technology (Institute of Marine Biochemistry, VAST, Vietnam). Additional research support was provided through the Ministry of Science and Technology of Vietnam (Grant number ĐTĐLCN.14/16).

\section{Supplementary Materials}

Figure 1S: HR-ESI-MS of 1. Figure 2S: ${ }^{1} \mathrm{H}$ NMR spectrum of 1. Figure $3 \mathrm{~S}:{ }^{13} \mathrm{C}$ NMR spectrum of 1 . Figure $4 \mathrm{~S}$ : HSQC spectrum of $\mathbf{1}$. Figure $5 \mathrm{~S}$ : HMBC spectrum of 1 . Figure $6 \mathrm{~S}$ : COSY spectrum of 1 . Figure 7S: NOESY spectrum of $1 .{ }^{1} \mathrm{H}$ and ${ }^{13} \mathrm{C}$ NMR spectroscopic data of isolated compounds 2-6. (Supplementary Materials)

\section{References}

[1] J. A. Beutler, R. H. Shoemaker, T. Johnson, and M. R. Boyd, "Cytotoxic geranyl stilbenes from Macaranga schweinfurthii," Journal of Natural Products, vol. 61, no. 12, pp. 1509-1512, 1998.

[2] P. H. Ho, An Illustrated the Flora of Vietnam, TrePublishing House, Ho Chi Minh, Vietnam, vol. 2, 1999.

[3] V. V. Chi, Dictionary of the Medicinal Plants in Vietnam, Tre Publishing House, Ho Chi Minh, Vietnam, 2012.

[4] S. Sutthivaiyakit, S. Unganont, P. Sutthivaiyakit, and A. Suksamrarn, "Diterpenylated and prenylated flavonoids from Macaranga denticulata," Tetrahedron, vol. 58, no. 18, pp. 3619-3622, 2002.

[5] X. Li, L. Xu, P. Wu et al., "Prenylflavonols from the leaves of Macaranga sampsonii," Chemical \& Pharmaceutical Bulletin, vol. 57, no. 5, pp. 495-498, 2009. 
[6] T. T. T. Van, D. T. M. Huong, P. V. Cuong et al., “Acetylcholinesterase inhibitors from the leaves of Macaranga kurzii," Journal of Natural Products, vol. 75, no. 11, pp. 2012-2015, 2012.

[7] P. Pailee, S. Sangpetsiripan, C. Mahidol, S. Ruchirawat, and V. Prachyawarakorn, "Cytotoxic and cancer chemopreventive properties of prenylated stilbenoids from Macaranga siamensis," Tetrahedron, vol. 71, no. 34, pp. 5562-5571, 2015.

[8] J. A. Beutler, J. Jato, G. M. Cragg, and M. R. Boyd, "Schweinfurthin D, a cytotoxic stilbene from Macaranga schweinfurthii," Natural Product Letters, vol. 14, no. 5, pp. 399-404, 2000.

[9] J. M. Joseph, "Phytochemistry and pharmacology of the genus Macaranga: a review," Journal of Medicinal Plants Research, vol. 8, no. 12, pp. 489-503, 2014.

[10] S. Phommart, P. Sutthivaiyakit, N. Chimnoi, S. Ruchirawat, and S. Sutthivaiyakit, "Constituents of the leaves of Macarangatanarius," Journal of Natural Products, vol. 68, no. 6, pp. 927-930, 2005.

[11] T. Péresse, G. Jézéquel, P.-M. Allard et al., "Cytotoxic prenylated stilbenes isolated from Macaranga tanarius," Journal of Natural Products, vol. 80, no. 10, pp. 2684-2691, 2017.

[12] T. Péresse, N. Elie, D. Touboul et al., "Dual beam depth profiling and imaging with argon and bismuth clusters of prenylated stilbenes on glandular trichomes of Macaranga vedeliana," Analytical Chemistry, vol. 89, no. 17, pp. 9247-9252, 2017.

[13] A. Huchelmann, M. Boutry, and C. Hachez, "Plant glandular trichomes: natural cell factories of high biotechnological interest," Plant Physiology, vol. 175, no. 1, pp. 6-22, 2017.

[14] T. Mosmann, "Rapid colorimetric assay for cellular growth and survival: application to proliferation and cytotoxicity assays," Journal of Immunological Methods, vol. 65, no. 1-2, pp. 55-63, 1983.

[15] D.-S. Yang, Z.-L. Li, W.-B. Peng et al., "Three new prenylated flavonoids from Macaranga denticulata and their anticancer effects," Fitoterapia, vol. 103, pp. 165-170, 2015.

[16] B. T. Ngadjui, E. Dongo, B. M. Abegaz, S. Fotso, and H. Tamboue, "Dinklagins A, B and C: three prenylated flavonoids and other constituents from the twigs of Dorstenia dinklagei," Phytochemistry, vol. 61, no. 1, pp. 99-104, 2002.

[17] T. Mei-Huims, C. Chang-Hung, C. Yih-Ming, and K. YuehHsiung, "Allelopathic prenylflavanones from the fallen leaves of Macaranga tanarius," Journal of Natural Products, vol. 64, pp. 827-828, 2001.

[18] A. Kamdemwaffo, P. Coombes, D. Mulholland, A. Nkengfack, and Z. Fomum, "Flavones and isoflavones from the west African fabaceae Erythrina vogelii," Phytochemistry, vol. 67, no. 5, pp. 459-463, 2006.

[19] B. J. Yoder, S. Cao, A. Norris et al., "Antiproliferative prenylated stilbenes and flavonoids from Macaranga alnifoliafrom the Madagascar Rainforest\#,1," Journal of Natural Products, vol. 70, no. 3, pp. 342-346, 2007.

[20] O. Thoison, E. Hnawia, F. Guiéritte-Voegelein, and T. Sévenet, "Vedelianin, a hexahydroxanthene derivative isolated from Macaranga vedeliana," Phytochemistry, vol. 31, no. 4, pp. 1439-1442, 1992.

[21] S. Almutairi, B. Eapen, S. M. Chundi et al., "New anti-trypanosomal active prenylated compounds from African propolis," Phytochemistry Letters, vol. 10, pp. 35-39, 2014.

[22] D.-S. Yang, S.-M. Wang, W.-B. Peng et al., "Minor prenylated flavonoids from the twigs of Macaranga adenantha and their cytotoxic activity," Natural Products and Bioprospecting, vol. 5, no. 2, pp. 105-109, 2015. 

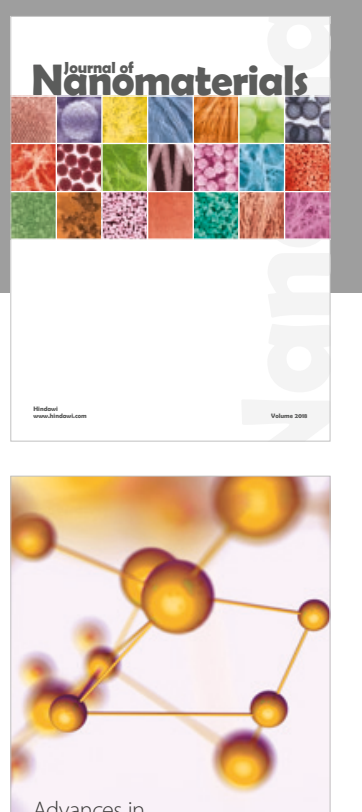

Physical Chemistry
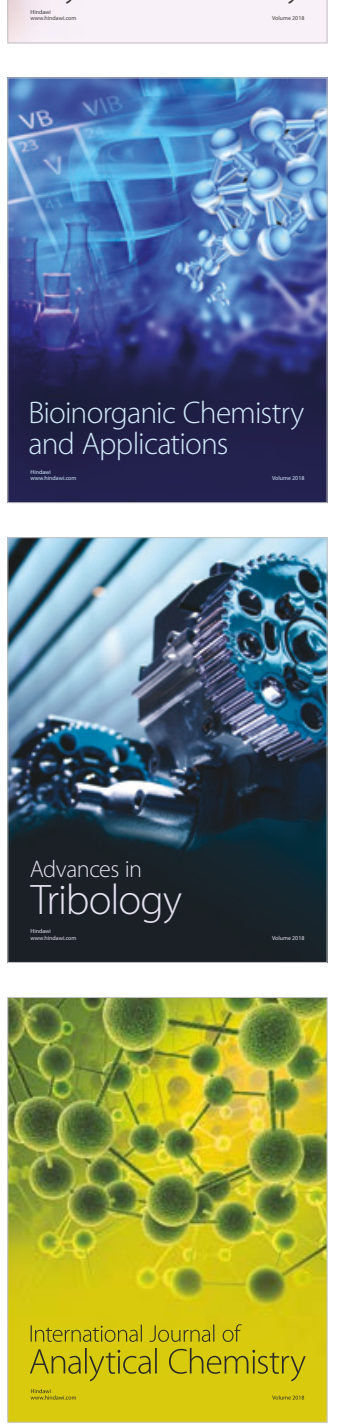

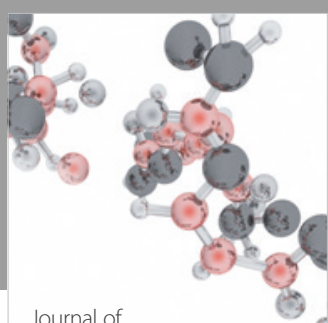

Analytical Methods

in Chemistry

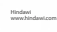

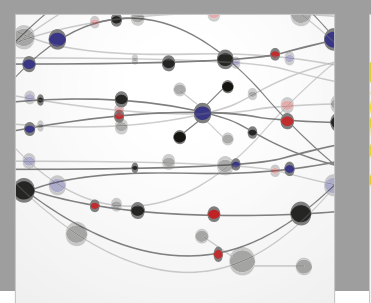

The Scientific World Journal

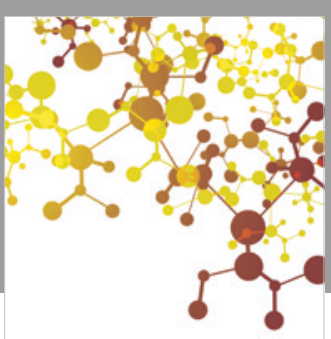

Journal of

Applied Chemistry
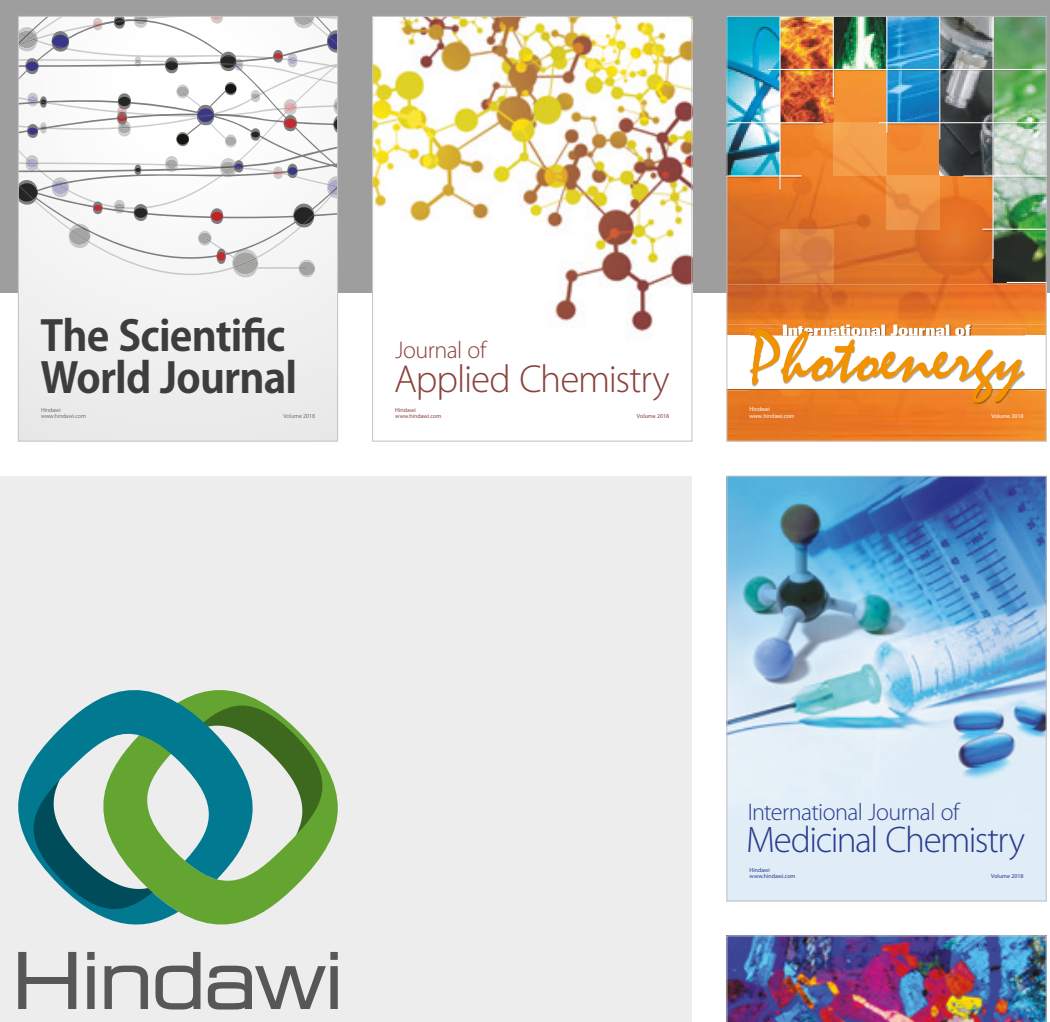

Submit your manuscripts at

www.hindawi.com
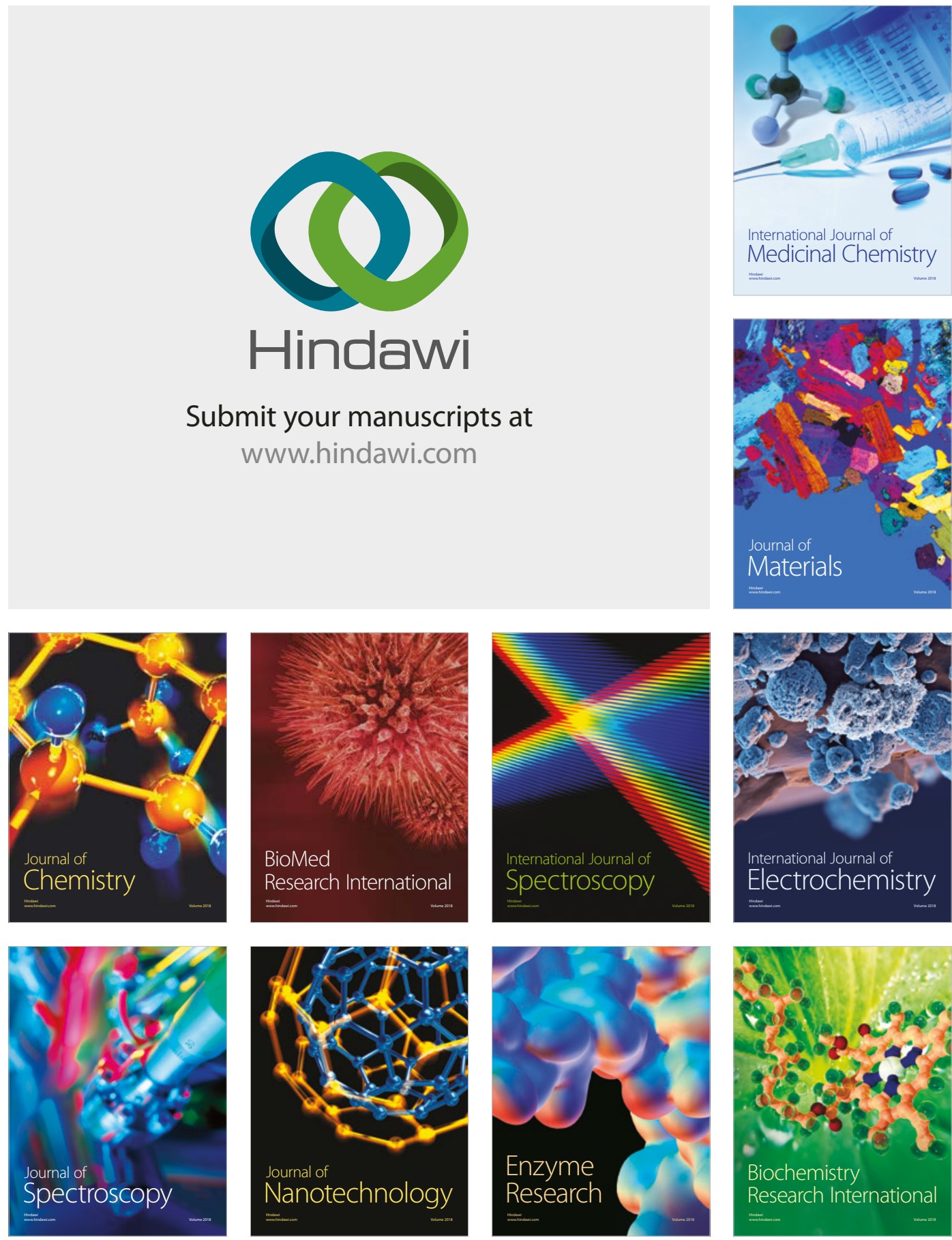
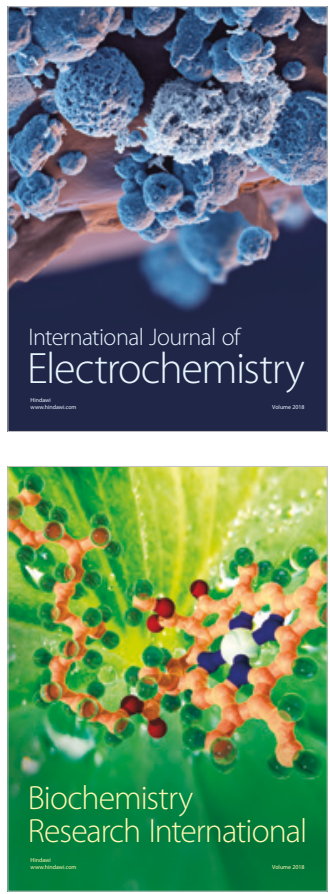